Dr. Sarah Badcock.

Lecturer in History,

University of Nottingham.

(Article published in Revolutionary Russia 2002, 15(1), pp. 69-96. )

'From Saviour to Pariah: A Study of the role of Karl Ianovich Grasis in Cheboksary during 1917.'

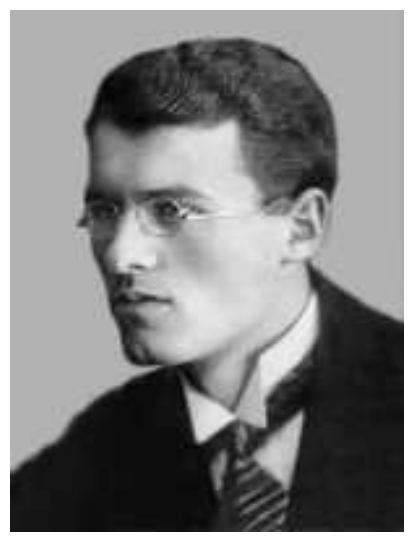




\section{From Saviour to Pariah: A Study of the role of Karl Ianovich Grasis}

\section{in Cheboksary during 1917.}

During 1917, severe public disorder and fierce infighting among local government organisations characterised life in Cheboksary town, a small town in Kazan guberniia. The nominal subject of this paper, Karl Grasis, is portrayed by various sources as playing a leading role in instigating and orchestrating these disturbances. The detailed analysis of events in Cheboksary presented in this article puts this colourful figure both in context, and into perspective. The turbulent course of affairs witnessed in Cheboksarskyi uezd, though unique in their locally specific manifestations, illustrate the difficulties of administering revolutionary Russia, and of trying to assess the role of specific individuals within the administrative structure. This article will start by outlining the general course of 'democratisation'" in the wake of the February revolution, and will consider the breach that existed between the main town, Cheboksary, and the surrounding countryside of Cheboksarskyi uezd. A profile of Grasis is presented, in order to acquaint the reader with this troublesome character, before going on to deal with the development of events in Cheboksary. The now outdated model of 'dual power' ${ }^{2}$ is overlaid with a far more complex picture of conflicts and harmonies among different levels and types of organisations in local government.

A number of historians have devoted attention in recent years to the provinces of Russia during 1917. ${ }^{3}$ Though my work more broadly fits into the tradition of regional study established by Donald Raleigh and Mike Hickey, this article does not attempt to offer a broad view of revolutionary events in Kazan guberniia.${ }^{4}$ Rather, the focus on a single town, Cheboksary, and the actions and influence of one man, Karl Grasis, offers an opportunity to elucidate the power struggle there, and in this way to provide 
broader illumination of the course of revolution in the Russian provinces, and insight into the role of the individual within the revolutionary process.

Grasis is an unusual example of a local leader of 1917 around whom it is possible to build up a more detailed picture of his background and personality. Though one can establish a general pattern of the social and educational background of local leaders, finding much information about a specific individual is rare. ${ }^{5}$ Up until the February revolution, the administrators and public figures of regional life in the uezds and guberniias were to some extent traceable. Those with suspect political connections were meticulously tracked by the secret police (okhrana), ${ }^{6}$ and the relatively restricted access to local administrative roles meant personnel remained fairly constant. The local leaders and activists of 1917 , on the other hand, are often anonymous figures. ${ }^{7}$ Very frequent changes in personnel, and the dramatic shift in the social background of such administrators from the pre-revolutionary intelligentsia and nobles, to the working peasant which dominated 1917, makes attempts to find individuals within lower level administration a difficult task. This very fluidity of the political scene gave individuals more scope to play a significant role, as they were less constrained by the framework of administration around them.

The February revolution heralded significant changes, not only in the mechanics of local administration, but also in popular expectations of government. The rhetoric of revolution promised equality, freedom and justice, while the practical and financial problems of providing material support were actually increased by the massive tumult of revolution. The ability of any administrative body, whether Soviet or Provisional Government sponsored, to employ the trust (doverie) of the population was crucial if it was to have any chance of long-term success in maintaining order among its constituency. Just what was required to win such trust is elusive; 'trust of the 
population' is an abstract concept, but was invoked as if it were a solid reality. Events in Cheboksary demonstrate that this abstract trust was an obscure phenomenon, which often revealed more about the perspective of the reporter than any real feeling among the population.

The diversity and local specifity of the organisations that developed in the wake of the tsarist administration's collapse are bewildering in their scope. The Provisional Government attempted to establish a local government network, which was responsible to central government, through the appointment of guberniia and uezd commissars, and executive committees at every level from guberniia down to volost and village. Alongside these committees the Provisional Government attempted to organise related but separate committees related to the provisions crisis (provisions committees) and for the organisation of use and preservation of land holdings (land committees). Various public committees, commonly named 'committees of public safety' formed in the immediate aftermath of revolution, often encompassing the most experienced administrators of the locality. These committees in some places formed a nucleus of support for the activities of the guberniia and uezd commissars.

The Soviets of soldiers, workers and peasants' deputies evolved autonomously. ${ }^{8}$ The Soviets are commonly regarded as examples of direct democracy; they were large councils, with representatives usually elected from their constituency by open vote. ${ }^{9}$ From these unwieldy bodies, an executive committee and a presidium were elected, which provided governance for the Soviet. They often worked very closely with the Provisional Government sponsored administration. There was enormous local variation in forms of administration, which demonstrate the creative, locally defined response to revolution. All these myriad forms held in common, however, their attempts to represent and defend all sectors of the community. In the case of the 
Soviet, this representation and defence was targeted specifically at all 'toiling and impoverished'(trudiashchiisia i obezdolennyi) people. The administration was under pressure to be formed either entirely from representatives elected by the local community, or at least for existing structures to be supplemented by such popularly elected representatives. A report to the Provisional Government for the period MarchMay nationally, commented:

Under the present system of popular elections, the idea of appointment did not fit in with national understanding. It suspected in this practice an encroachment upon its liberties $\ldots{ }^{10}$

A reporter on events in Cheboksary remarked:

The revolutionary People must take power away from the bureaucrats and deliver the country from disorder. We need to move away from the former situation. We must have regional government of the moment, elected by four-tailed suffrage, otherwise the government will be regarded by the people as 'decorations'. ${ }^{11}$

Cheboksary town became the capital of the newly formed Chuvash republic in 1922, indicating its status as the most important town in the region. Prior to the revolution, however, this small town had little to distinguish it from many other settlements in the mid Volga region. ${ }^{12}$ In 1914, it had just two stone built streets, a population of around 6,000 , and 'it resembled nothing more than a dirty village'. ${ }^{13}$ Cheboksary's dubious claim to fame was as a staging post on the journey of Siberian exiles along the infamous Vladimirka tract. Industrialisation had barely touched Cheboksary; its biggest industry was the Efremov saw mill factory, which employed 165 workers. The total worker population of Cheboksary in 1917 was 'no more than 300 '. ${ }^{14}$ The onset of war in 1914 caused significant shifts in the town's population, as many local men were called up, parts of the $94^{\text {th }}$ and $95^{\text {th }}$ Infantry reserve regiments were stationed in 
town, and 'beggar peasants impoverished by the war streamed into the town'. ${ }^{15} \mathrm{~A}$ political exile returning to the town in early July 1917 remarked that:

the little uezd town Cheboksary seemed to me just as shabby as I had known it earlier . . . there was impassable mud in the streets. ${ }^{16}$

There were marked differences in the ethnic constitution of the town and uezd. (See table I). The almost entirely Russian population in the town, alongside a tiny number of Russians in the uezd population, is typical of the pattern of population distribution in Kazan guberniia. ${ }^{17}$ This ethnic disparity between town and village led to an even higher degree of disassociation between town and village than is usually noted. Cheboksary town was the administrative base for the uezd, and the uezd's senior administrators were accordingly predominantly Russian. In addition to the usual mistrust witnessed between town and countryside residents, the Chuvash and Marii, two entirely separate national minority (inorodtsy) groups, did not share language, culture or religion with the Russians. ${ }^{18}$ The climate and preferences of the town were by no means a reflection of the more general mood of the uezd.

$\underline{\text { Table I, showing the ethnic constituency of Cheboksarskyi uezd in } 1917 .{ }^{19}}$

\begin{tabular}{|l|l|l|l|l|}
\hline & Russian & Tatar & Chuvash & Marii \\
\hline $\begin{array}{l}\text { Uezd } \\
\text { Population }\end{array}$ & 19195 & 5043 & 116149 & 22286 \\
& $(11.8 \%)$ & $(3.7 \%)$ & $(71.4 \%)$ & $(13.7 \%)$ \\
\hline $\begin{array}{l}\text { Town } \\
\text { Population }\end{array}$ & 6127 & 47 & 583 & 14 \\
& $(90.4 \%)$ & $(0.7 \%)$ & $(6.4 \%)$ & $(0.2 \%)$ \\
\hline
\end{tabular}

Land relations, generally a key area of conflict in the countryside in 1917, were unusually harmonious in Cheboksarskyi uezd. The lower proportion of privately held land there was a factor in this relative peace. ${ }^{20}$ Another significant factor in low levels of land conflict was the Kazan Soviet of peasants' deputies decree of 13 May that all 
privately held land, with the exception of small seperators' (otrubniki) holdings, ${ }^{21}$ was to be transferred to volost land committees prior to the discussion of the land question by the Constituent Assembly. ${ }^{22}$ This was enacted by volost and uezd committees in Cheboksarskyi uezd, with the result that there was very little indiscriminate land seizure. ${ }^{23}$ In a meeting of Cheboksarskyi volost and uezd commissars, held in June 1917, the main feature of public disorder was unauthorised cutting of wood; a wood committee was formed in June, which was to have an inbuilt Soviet majority, to deal specifically with this problem. ${ }^{24}$ The journal of the general meeting of Cheboksarskyi uezd land committee on 1 August confirmed the impression given by the June meeting, and presented a relatively harmonious picture of the state of affairs in the $u e z d$. Reports on land affairs were heard by representatives of all the volosts, and no violence, seizure or serious disturbance was noted anywhere, a rarity in 1917. The overall picture was one of calm and well regulated management of land use and rental. $^{25}$

Political and class based conflict in the countryside was at a much lower and more sporadic level than that witnessed in Cheboksary town. The Socialist Revolutionary party (PSR) enjoyed political dominance in Cheboksarskyi uezd, as in most other rural districts in the Volga region. ${ }^{26}$ The overall impression of the uezd was, in contrast with other uezds of the guberniia, relatively peaceful; the idea of a peasantry split by poverty, land use or political ideology was not in evidence. Reports on the July zemstvo elections in the uezd showed that turnout fluctuated wildly from volost to volost, ${ }^{27}$ and in nine of the ten volosts described, it was stated that, 'For lack of class or political struggle, lists were formed by groups of villages. ${ }^{28}$ Krynetskii, a $^{2}$ participant in the Cheboksary Soviet, described the agitation work carried out by the Soviet, and despite his enthusiasm for depicting the popularity of the Soviet's pseudo- 
Bolshevik position, he did not refer to the rural population's responses to Soviet agitation until October. Then he noted that 'several volosts, far away from Cheboksary, yielded to (the Soviet's) agitation'. This implied a lack of enthusiasm for the Soviet cause. Only four volosts sent representatives to a meeting of the Cheboksary Soviet on 22 October, where they reportedly condemned the 'bourgeois Provisional Government' ${ }^{29}$

This impression of relative calm contrasts sharply with the political tumult and public disorder seen in Cheboksary town. There was wide popular involvement in revolutionary affairs in Cheboksary town; an enthusiastic revolutionary reported that at the 1 May celebrations in Cheboksary more than 4,000 people attended, in a town of less than 7,000 residents. ${ }^{30}$ In the first month after revolution, as in Kazan town itself, a committee of public safety formed, which was dominated by 'zemstvo employees and the tsenzovyi element. ${ }^{31}$ Here, however, all ground for comparison ends. In Kazan town, the Soviet leaders themselves recognised that the Soviet was not sufficiently organised to take over the administration of the guberniia, and fully supported the committee of public safety, which was significantly enlarged on 10 April, and whose 260 members included representatives from all sections of the community. ${ }^{32}$ 'There was no question of dual power in Kazan. ${ }^{33}$ In Cheboksary, on the other hand, the administration was riven with dissent from the outset of the revolution.

All the sources indicate that Karl Grasis as the focal point for the dissent and political activism in Cheboksary, and as being at the fulcrum of revolutionary activities. He was described variously by his opponents as a pogromist, a student, a German spy and provocateur, ${ }^{34}$ and as having declared affiliation with political parties of every shade from Kadet to Bolshevik. ${ }^{35}$ Both his supporters and his opponents in Cheboksary 
regarded him as the individual around which public life rotated during 1917 . One commentator noted that:

Grasis is not representative of any well-known world outlook, but his convictions, and his alone, as an individual, are the centre of local life, and everything turns around them. ${ }^{36}$

He was lauded as the figurehead of revolution by his supporters, and accused of leading pogroms, counter-revolutionary activity and corruption by his opponents. Members of the Cheboksary town provisions committee reported that:

Where he came from is not known, how he lives is also not known. This Grasis gets rich in Cheboksary. ${ }^{37}$

Grasis was only 23 years old in $1917 .{ }^{38}$ Born to a poor Latvian family, he studied at the local parish school, then the gymnasium, and in 1912 enrolled in the National University of Shaniavskyi in Moscow. He was a man of exceptional literary talent; he first produced published work at the age of thirteen, and went on to write and edit a huge range of political and literary publications. ${ }^{39}$ He was a talented orator, if rather verbose; his speech in the Kazan Soviet of workers and soldiers' deputies on 22 April was so extensive that on its conclusion a resolution was quickly passed limiting orators' speeches to ten minutes duration. ${ }^{40}$

Grasis had been arrested in 1915 for spreading revolutionary propaganda, and exiled to Kharkov. In August 1916 he was sent to Cheboksary on administrative exile. ${ }^{41}$ Cheboksary was reportedly chosen as his place of exile because as a town in a remote location with a small garrison, it minimised Grasis' threat to public order. Despite the apparently innocuous nature of the town, however, Grasis reportedly made connections with soldiers in the garrison stationed there and with regional workers. He set up an underground press in 1916, and printed a number of anti-government leaflets. ${ }^{42}$ There was clearly some confusion about Grasis' liability to military service; 
Kazan's military district commander sent an order to the guberniia commissar in May 1917 that Grasis had been called up to active service in 1915 , and that he was to return immediately to his regiment. ${ }^{43}$ His Soviet biographer comments that attempts were made by his opponents to 'send him to the front', but that his health meant that he was not fit to serve. ${ }^{44}$ Lack of other references to military service by his detractors, in a climate when deserters and shirkers were routinely rooted out and demonised, would suggest that his avoidance of military service was indeed legitimate.

Politically, Grasis associated with the Social Democrats from his earliest days. In the first months of 1917, he descibed himself as a Latt Menshevik, and he was excluded from the Latt Social Democrat organisation at the end of July. ${ }^{45}$ His Bolshevik credentials soon became apparent however; Grasis organised the publication of Lenin's April Theses in Cheboksarskaia Pravda, wrote a brisk editorial defending them, and in June voted against the then leader of the Kazan Bolsheviks Kvasnikov, who opposed Lenin's policies. ${ }^{46}$ Grasis did not formally join the Bolsheviks till May $1917,{ }^{47}$ but was reportedly already recognised as the leader of regional Bolsheviks by June. ${ }^{48}$ He was made president of the Kazan Bolshevik organisation in September, and was elected first president of the revolutionary staff formed in Kazan by the Soviet of workers and soldiers' deputies in the wake of the October revolution. ${ }^{49}$

Despite Grasis' position as one of Kazan's leading Bolsheviks, he did not form a Bolshevik party cell in Cheboksary; indeed, the Bolsheviks did not establish any sort of party political organisation until January $1918 .^{50}$ This is significant, as it indicates that in Cheboksary party political delineations were of much less significance than the politics and actions of any given individual. E.G. Vinokurov, a Bolshevik veteran who was active in Cheboksary during 1917, recalled an incident when a friend approached him to cheerfully inform him that she had joined the PSR. He replied that she had 
made a mistake, since Grasis was a Bolshevik, who was against all the bourgeoisie. Her response was that she had not known, and would go and join the Bolsheviks at once. ${ }^{51}$ Though Grasis himself was highly politically aware, it was not party politics that attracted support to him, but his prestige and infamy within the locality.

A description of Grasis written in early April 1917 by the then Cheboksarskyi uezd commissar, M. Bocharov, is an interesting summary of his persona and activities:

Karl Ianovich Grasis, as an individual, has the gift of the gab, and has a talent for attracting the common people (narodnyi mass) to him. . Grasis seems to be driven, that is, he began to attract the common people to his side, while striving for some sort of aims of his own. . he formed meetings almost daily, by repeating one and the same thing, a critique of the actions of the local zemstvo. It goes without saying that the actions of the Cheboksarskyi zemstvo irritates the whole population of the uezd. Grasis, as a highly intelligent person, understands extremely well that he can build up his popularity better this way than by any sort of creative work. . Grasis became a well-known face in town and in the surrounding villages. It is necessary to acknowledge that most of Grasis' work is accomplished in the business of exposing the zemstvo system. ${ }^{52}$

One man that could be regarded as something of a counterpoint to Grasis in Cheboksary was Trofim Prokhorovich Prokhorov. Like Grasis, he was a controversial figure with an uncertain past, whose background and political activity provoked dissent and controversy. ${ }^{53} \mathrm{He}$ was elected uezd commissar in mid April, initially with the full support of Grasis and the Cheboksary Soviet. A report in Kazanskaia rabochaia gazeta described him as 'an old revolutionary worker', and his election signified for the reporter 'the final destruction of the old regime. ${ }^{54}$ It is reported that he was initially very critical of zemstvo adminstration and the 'bourgeois' administration, but that once he had established his own power base, he supported the 
'bourgeoisie' and struggled against the Soviet. ${ }^{55}$ Politically, his orienation was confused by later commentators; he was described variously as a 'leading SR', as a Menshevik, and as a fanatical Chuvash nationalist. ${ }^{56} \mathrm{He}$ was also credited with offering full support to the Provisional Government and 'war till final victory', a typically Kadet phrase..$^{57}$

The Chuvash newspaper Khipar, an SR Nationalist publication, asked the rhetorical question 'Who is this Prokhorov?', with the answer that he was first and foremost a Chuvash, and that the foul rumours spread about him had been spread by Russians. The implication here was that Russians were not to be trusted with Chuvash affairs. ${ }^{58}$ This was no doubt a reference to the 'outsider' Grasis and his cohort of soldier and sailor supporters. The Bolshevik newspaper Rabochii reported that Prokhorov travelled around the uezd inciting the Chuvash people against Russian workers. ${ }^{59}$ This is the rare example of evidence of tensions between Russian and Chuvash elements of the population in Cheboksarskyi uezd. Both the Chuvash and the Russian elements of the press highlighted the division which existed between the 'native' Prokhorov and the 'outsider' Russians. Grasis, as a Latt, who may well have had an accent which would have further identified him as an outsider.

Prokhorov is an excellent example of the uncertain nature of the quality of 'trust of the population'. Though Cheboksary Soviet sources described him glowingly at the end of April, within a month he was no longer on good terms with Grasis, and unsavoury rumours circulated about him. An anonymous peasant from Prokhorov's home volost sent a denouncement of Prokhorov to the guberniia commissar, claiming that he had been tried and punished by Vilensk regional court. ${ }^{60}$ The guberniia commissar took this claim seriously enough to make an investigation of the matter. The public prosecutor of Vilensk regional court reported that no legal actions had 
been undertaken against Prokhorov in the region. ${ }^{61}$ Further investigation of Prokhorov's past, however, substantiated these rumours. It emerged that when in active military service in 1905, he had absconded from his regiment with 755 roubles, and lived abroad for more than six months. When he returned to Russia, he served in a punitive military command. ${ }^{62}$ Prokhorov apparently continued his unsavoury behaviour in 1917. He owned land in Pokrovskii volost, and at the village meeting (skhod) on 29 April menaced his fellow villagers with threats of soldiers being sent if they did not hand over some common land to him. ${ }^{63}$ The 'old revolutionary worker' had a distinctly dishonourable past, and his personal unpopularity became the focus of a number of violent demonstrations in the town.

A struggle for power developed between the Soviet, headed by Grasis, and other elements of the town administration, including Prokhorov. A meeting which formed in one of Cheboksary's parks on 8 March, attended by peasants from neighbouring villages, gives some indication of the rawness of the conflict which developed between Grasis and the town administration. The uezd commissar Ennatskyi reportedly tried to incite the crowd against Grasis, and called on them to 'Beat the swindler!'. Grasis was protected by a group of armed soldiers and workers, and in the confrontation that followed, Ennatskyi was forced to sign a paper standing down from the commissariat. ${ }^{64}$ This incident, recounted in Grasis' biography, is not described in other sources, and one has to be cynical about its veracity- in particular, the detail of 'armed workers and soldiers' (the traditional proletarian harbingers of revolution) defending Our Hero Grasis against the mob law (samosud) of the dark peasant masses is rather too tidy to be wholly plausible. Probably as a result of these disruptions, 94 soldiers from the $94^{\text {th }}$ Infantry reserve regiment, accompanied by seven officers, were sent to Cheboksary from Kazan at the beginning of March, and more soldiers were 
sent at the end of March. These soldiers however sided with Grasis, and so did not carry out their stated duties of defending the Provisional Government administration. ${ }^{65}$ As a result of 'constant threats from counter-revolution', Grasis was accompanied wherever he went by three soldiers, Ivan Penzin, Gavrilov and M.I. Ivakin. ${ }^{66}$ This trinity bodyguard was remarked upon in a very hostile light by a number of commentators, ${ }^{67}$ but no doubt added to the aura of prestige and importance developing around Grasis.

Grasis was extraordinarily hostile to former zemstvo workers, and intelligentsia figures generally. His slogan from the outset was 'Down with all officials!' The Cheboksary soviet's refusal to allow co-operative representatives to participate in the uezd's provisional administration is an indication of such hostility, as well as the independent and authoritative line taken by Grasis. ${ }^{68}$ The guberniia commissar reprimanded the Soviet, and warned that such matters were not within its jurisdiction. ${ }^{69}$ This is an interesting early reminder of the difficulties surrounding power and authority; Grasis clearly felt under no obligation to conform to the power structures established by the Provisional Government, and his independent actions actively undermined their representatives.

The situation in Cheboksary polarised into two clearly opposing organisations, both vying for power. The Soviet of workers and soldiers' deputies ${ }^{70}$ was formed at Grasis' initiative in April. It had 46 members, an executive committee of eight men, and published a newspaper, Cheboksarskaia Pravda. ${ }^{71}$ The Soviet took a radical stance from the outset; it opposed the Provisional Government and organised a number of cultural-enlightenment events, such as cinema showings and a production of Gorkii's 'Na dne'. ${ }^{72}$ Grasis reportedly dominated the Soviet imperiously. A delegate from the 
Kazan Soviet attended one of the Cheboksary Soviet's meetings in June, and stated that:

Grasis actively managed all Soviet (activity). There was no-one objecting to him for this, but almost all the members of the Soviet collaborated (in this domination by Grasis). ${ }^{73}$

Against Grasis' Soviet was pitted the town and uezd executive committees, sponsored by the Provisional Government. An investigative committee instigated by the Kazan Soviet reported that the conflict between the two organisations stemmed from Grasis' hostility to his removal as captain of the militia. ${ }^{74}$ Other sources indicate deeperseated grounds for hostility. From the outset, Grasis ranged himself against all former administrators in the most unconciliatory terms. He held frequent meetings in Cheboksary town, at which he agitated against all the members of the executive and provisions committees. The slogans of these street meetings included 'Don't sign up to the War Bonds!'(Zaem Svobody) ${ }^{75}$, 'Down with the War!' 'Down with the Provisional Government!'.76

Grasis made attempts to hold agitational meetings in the outlying rural areas of the volosts as well as in town. A detailed account written by a bystander of the course of a meeting in Kozlovko village provides an interesting insight into Grasis' temperament and political method, and suggests that Grasis' radical message was not accepted everywhere. Kirillov commented on Grasis' visit to Kozlovko that 'there at a meeting he directed the peasants not to wait for the Constituent Assembly, but to confiscate landowners' (pomeshchik) land at once. ${ }^{, 77}$ Other accounts indicate that this description of Kozlovko events is misleading. Grasis travelled to Kozlovko village on 25 May, accompanied by two students. His companions, who declared themselves to be SRs, and of whom one was known by a villager, were welcomed, and held a successful and peaceful meeting to organise a peasants' union, and to draft resolutions 
on the land question. Grasis, however, from his first minutes in the village provoked the mistrust and hostility of the population. On arrival he announced himself to the people gathered there as captain of Cheboksary town militia. As he was unable to produce documents verifying this status, however, the crowd declared that they would hear him only as a student, and not as a militia captain. He was extensively questioned in the course of his afternoon's visit, on his background and his activities in the uezd, rumours of which had reached Kozlovko. His answers were highly evasive, but his actions in the course of the afternoon provide a valuable indication of his personality. Grasis was a fiery, impetuous and self-important character. His recent successes on the public stage in Cheboksary had clearly swelled his ego as well as his confidence. Three times in the course of the day he used aggressive or coarse language in describing Kozlovko officials, which excited the angry censure of the crowd. When discussing the chief of militia Orlov, for example, Grasis said:

"If Orlov, the militia superintendent, is not trusted by the population then to the devil with him!" The people (narod) protested against harsh words and attacks. ${ }^{78}$

Grasis, as seemed to have been his trademark, tried to pit the intelligentsia and the old zemstvo workers against the 'true people' (narod). In Kozlovko, however, this was not a fruitful tactic, as the zemstvo workers were well liked by the population. ${ }^{79}$ Grasis tried to send a telegram to Kazan demanding Soviet deputies be sent to Kozlovko, but was prevented by the local militia chief Lunin. Clearly infuriated, Grasis shouted as he left the telegram office at the crowd that had gathered there, 'You will be made to toe the line! I will bring you to court! ${ }^{80}$ These rash words provoked the crowd, who shouted 'Down with him!' and threatened Grasis. His personal safety was only secured by the intervention of Lunin. His threat on leaving was not an empty one. On 27 April, five deputies from the Cheboksary Soviet, along with three members of the 
uezd executive committee, arrived in Kozlovko to conduct an 'investigation into the misunderstanding' that had occurred. An overwhelming majority of the meeting of residents gathered by these representatives of uezd authority made a vote of no confidence against Grasis. As a result of these preliminary investigations, no further action was taken. ${ }^{81}$

In June, there were repeated outbreaks of public disorder, pogroms and violence towards administrators in Cheboksary. The causes for these outbreaks are complex. Some commentators put the violence down entirely to the agitational activity of Grasis, while others blamed the massive unpopularity of the uezd commissar Prokhorov. Public fears and rumours regarding the provisions situation were undoubtedly a major factor in these disturbances. Though commentators tended to emphasise the role of Grasis in leading such disorder, remarkably similar incidents elsewhere in the guberniia and in Nizhnii Novgorod are a strong indication that the provisions crisis was of greater significance than the person of Grasis. Another possible cause of unrest, which was not remarked upon by Grasis-obsessed commentators, was the more traditional patterns of regional unrest. As early as 18 May, worrying rumours were circulating about forthcoming disorder in Cheboksary that was being planned for the Troitskii holiday. The town alcohol store administrator appealed to the guberniia commissar to strengthen the defence of known state wine stores in the town, and those places with large reserves of denatured spirit intended for Kazan shell factory. ${ }^{82}$

Just as in towns all over Kazan and Nizhnii Novgorod, ${ }^{83}$ the population in Cheboksary directly threatened the members of the provisions administration. This reflected town residents' concerns about forthcoming provisions shortages, and the direct personal responsibility placed upon hapless administrators for these shortages. What is unusual 
about the events in Cheboksary was that members of other branches of the town administration actively participated in these riots (bunty). This is not a phenomenon that was apparent in other towns, and indicates the harshness of the conflict between different individuals, and different branches of the administration. Grasis was clearly not the only problematic member of Cheboksary's administration.

There can be no doubt, however, that Grasis took a leading role in instigating attacks on the provisions administration. At the end of May Grasis had gathered a crowd of soldiers' wives (soldatki), and announced that there were large provisions reserves, but that the provisions committees were not permitting them to be distributed. ${ }^{84}$ The crowd challenged the provisions committee, who clarified that there were reserves, but that these had been donated by Iadrinskii uezd for distribution to the army, to hungry uezds and guberniias. ${ }^{85}$ Such protest went further on 5 June, when the president of the Cheboksarskyi uezd provisions administration, Andrei Stepanovich Kozlenikov, was attacked at the town administration's building by a predominantly female crowd of some 200 town residents. The main instigators of this crowd were themselves members of the town administration. Initially the crowd demanded supplies of good white flour, and personally insulted Kozlenikov. They then threatened to throw him from a second floor window. This intimidation by the crowd forced Kozlenikov to immediately sign an authorisation for the supply and distribution of white flour to the town residents. This action did not however end Kozlenikov's trial. He was reproached for permitting the export of flour from Cheboksary, and the crowd decided to take him down to the river station to search for provisions reserves. Nothing was found except malt. As a result of this incident, Kozlenikov asked to resign his post. ${ }^{86}$ 
This rising indicates the insularity of the town population's view of the provisions question. Kozlenikov was condemned for allowing grain export, even though the crisis situation of other guberniias, to say nothing of the army, was well advertised. It is also significant to note that the demands focused on white flour, a product generally regarded as a luxury, especially outside the towns. Kazan guberniia produced grain for export, and grain shortages there were not so widespread in 1917, yet demands for provisions were just as vociferous as in hungry guberniias like Nizhnii Novgorod, and encompassed, instead of cries for the staple of life, demands for sugar and white flour. ${ }^{87}$ Where there was a shortage, even if, like sugar, it did not threaten life, this shortage became a major issue of the day, and took on equivalent, or even greater force than demands for bread in a hungry guberniia. ${ }^{88}$

The assault on Kozlenikov was only the beginning of a spate of disorders in Cheboksary. Cheboksary Soviet deputies agitated among the 500 soldiers who had returned to Cheboksary from the front for field work. Many soldiers were persuaded to abscond from their regiments and remain in Cheboksary. ${ }^{89}$ These men were a volatile and dangerous addition to the already strained situation in the town. The peak of the June disorders occurred at the extraordinary meeting of the town committee of public safety called on 22 June. At the request of Prokhorov, two agitators had been sent from Kazan, along with the State Duma Provisional Committee's commissar Rossolovskii, to investigate the causes of public unrest in Cheboksary. Rossolovskii chaired the meeting, which developed into a confrontation between opponents and supporters of Grasis. Grasis attended the meeting as delegate for the Cheboksary Soviet and the 'Union for evacuee military' (this 'union' no doubt represented the deserting soldiers based in Cheboksary). Grasis immediately presented a motion of no-confidence in Prokhorov. Rossolovskii, however, challenged Grasis' attendance at 
the meeting, declaring that he was a 'foreign enemy' (zamorskii vrag), who had no place there. As a result of Rossolovskii's intervention, the meeting voted to exclude Grasis from participation.

At this point however, the presidium was stormed by the soldiers on leave who crowded the audience. Prokhorov himself escaped through an open window, and fled to Kazan town on the first steam boat down the Volga. The two incoming agitators and Rossolovskii were beaten up by the crowd, and Rossolovskii was taken to prison. Grasis intervened to have Rossolovskii freed, on condition that he signed an agreement not to return to Cheboksary. ${ }^{90}$ In a frantic telegram sent from a neighbouring suburb (posad) of Marinskii, Rossolovskii sent news of events to the guberniia commissar. He named a Kronstadt sailor, Khalapsin, ${ }^{91}$ as the man who beat him up, ${ }^{92}$ which confirmed the prominent role taken in these events by incoming soldiers. Representatives from the Kazan Soviet of soldiers and workers' deputies and the Kazan committee of public safety came to Cheboksary on 24 June to investigate the apparent chaos. They attended the Cheboksarskyi uezd committee of public safety meeting, where statements and clarifications were made about the situation in the town. As a result of their investigation into the uezd commissar Prokhorov, it was recommended that he be removed. He was replaced by the SR M.A. Alekseev. ${ }^{93}$ The investigative body further ruled that the uezd committee of public safety was to be reorganised on democratic bases, with representatives from every volost. The State Duma emissary Rossolovskii was not at all satisfied by the actions of the investigative body, and placed significant responsibility for the disorder on Grasis personally. His telegram on 26 June to the captain of Kazan military district staff painted a picture of total lawlessness: 
The terror in Cheboksary develops every minute. It is necessary (for me) to leave. A range of pogroms were carried out in Marinskii suburb today. Wine stores and the zemstvo factory remain without defence. The delegates that were sent are not up to the mark. One, seemingly a Bolshevik, went over to the side of Grasis. The remainder are voiceless. Grasis at today's meeting openly provoked the population's pogroms. The investigator does not have support, and is denied the possibility to carry out arrests. The militia is passive. They assist the pogromists with looting of wine stores. Carnage will begin. I beseech you to take measures in view of the inevitable violence. Terrorists will interpret inaction of the guberniia authority as encouragement, and support is necessary. Rapidly send armed soldiers. A minute's delay threatens calamity. ${ }^{94}$

This call for armed assistance was a cry heard all over the guberniia with repeated frequency as the summer wore on. The guberniia commissar ordered that Cheboksary's military command be replaced with a new command of 50 soldiers, and an officer. ${ }^{95}$ Grasis, meanwhile, sent a telegram to the guberniia commissar asking him not to send armed force to Cheboksary. He also demanded that the uezd commissar Prokhorov be arrested in order to preserve public order. ${ }^{96}$ At the end of June, the guberniia commissar summoned Grasis to Kazan town in order to provide further clarification of events. ${ }^{97}$ Despite Grasis' protests, soldiers were sent to Cheboksary, in twice the number initially requested, 100 soldiers accompanied by 2 officers, in order to take measures for the pacification of the town. ${ }^{98}$

The uezd provisions committee reported to the guberniia provisions committee at the beginning of July that Grasis led an anarchist movement, and provoked fierce hostility towards grain requisition in the uezd. Grasis and his 'company of pogromists' had allegedly physically threatened the town executive committee, and incited the population against them. ${ }^{99}$ At this meeting, Prince Kropotkin 'foaming at the mouth, declared that it was necessary to send 10,000 soldiers to Cheboksary to capture 
Grasis. ${ }^{100}$ The Cheboksary Soviet denied these claims that Grasis was a pogromist, and stated that though his slogan was indeed 'Down with all officials!', he had never spoken on the provisions question, and indeed could be considered to be a calming influence. ${ }^{101}$ While there is no doubt that Grasis himself formed a core of hostility towards the town administration, to credit him with instigating hostility to grain requisition in the uezd is far fetched. All over Kazan guberniia, the village population showed resolute hostility to grain requisition, and in some places refused even to allow their households to be registered for the vote in attempts to avoid the grain monopoly. This hostility tended to be particularly marked among the non-Russian population, so that Cheboksarskyi uezd, with its big Chuvash population, could be expected to show such resistance. ${ }^{102}$

Though Grasis cannot be credited with initiating provisions disorder, his influence on town life was certainly not conducive to ordered administration. The guberniia commissar, Chernyshev, was clearly concerned about the situation in Cheboksary. He had received reports on 2 July of an inflammatory meeting held in Cheboksary held by 'an unknown soldier' that threatened to provoke mass unrest. ${ }^{103}$ Chernyshev's emissary to Cheboksary reported Grasis' activities thus:

(He provokes) exceptional disorganisation in the administration of the uezd. . He does not have the faith of individuals on all sides of the population ... ${ }^{104}$

At the beginning of July the Cheboksary Executive Committee ordered Grasis' arrest. The reasons for this arrest were that:

His agitational activities are directed towards the discrediting of both the aims and the power of the Provisional Government, and Grasis brings disorder and arms one part of the population against the other; he is clearly criminal and provocative in his actions. ${ }^{105}$ 
Grasis, however, had the support of Cheboksary town garrison. At the garrison's meeting on 3 July, the order for the arrest of Grasis and his cohort was discussed. The meeting expressed indignation about the order for Grasis' arrest, as it violated personal immunity, and heralded the $164^{\text {th }}$ regiment, who had refused to carry out the order to arrest Grasis. ${ }^{106}$ Despite these protests, Grasis and part of his "pogrom company' were successfully arrested and directed to Kazan town. ${ }^{107}$ This account written by E. Liuminarskaia, Grasis' landlady, gives some indication of the importance attached to his successful arrest:

They came for him at $2 \mathrm{am}$. Just as we opened the doors, soldiers with fixed bayonets formed a corridor on both sides of the stairs going up to Grasis' room on the second floor. We were forbidden from speaking with the arrested man. Grasis was sent to Kazan. ${ }^{108}$

On 3 July, some two thousand people formed a popular demonstration in Cheboksary town. There was clearly uncertainty about Grasis' arrest; they asked that if he had been arrested he should be freed and sent back to Cheboksary, and if not, then the commissar must sign to confirm that he was to remain at liberty. The real focus of this meeting, however, was not Grasis' arrest, but demands for the reorganisation of the committee of public safety. This again emphasises that Grasis, though an important individual, was not the most important feature of Cheboksary life. The uezd commissar Prokhorov was the focus for the meeting's hostility; the protocol of the meeting declared twice that he was to be sent to the front without delay. Prokhorov and individual members of the uezd committee, who were named specifically as not having the faith of the people, were brought before this manifestation, and each forced to sign a personal statement, agreeing to submit to the demands of the crowd. ${ }^{109}$ One can speculate that the submissive committee members later reneged on their apparent willingness to stand down and to be sent to the active army; an appeal was made to 
the guberniia commissar by the executive committee members for the sending of loyal armed strength on 5 July. ${ }^{110}$

The Cheboksary Soviet unsurprisingly issued a protocol declaring a formal protest with regard to the arrest of Grasis, and the infringement of personal freedoms it invoked. ${ }^{111}$ The Soviet claimed that Grasis' personal enemies, including the uezd commissar Prokhorov, ordered this arrest. ${ }^{112}$ The guberniia commissar, meanwhile, found the uezd commissar's protocol regarding the arrest of Grasis correct, and sent one of his assistants to Cheboksary to clarify matters. ${ }^{113}$ Once in Kazan, Grasis was asked to stand before the Soviet 'for talks'. Grasis' own words describe his investigation before the soldiers' section of the Kazan guberniia Soviet, held on 10 July:

The majority there sat in golden epaulets. After a two hour discussion about the foundations of a lawful state, about the Provisional Government and the Constituent Assembly, it was decided to arrest me and to imprison me in the main guard house, without considering this, that the Menshevik jurists taking part in the discussion displayed staggering ignorance of legal literature. When, citing Esmin from memory, I declared that in the opinion of jurists the whole Provisional Government used power unlawfully, I heard in answer 'This cannot be!'114 Grasis' knowledge of the law and articulate manner may have taken the Soviet members aback, but it did not stop them from agreeing that he was a harmful influence on local life, and authorising his continued incarceration. Grasis wrote a letter on 13 July from his cell in Kazan jail, complaining that the days of arbitrary arrest were not over. ${ }^{115}$ He kept busy in the course of his two month imprisonment, writing a book Neizbezhnoe budushchii (The Inevitable Future), which was published later in 1917. 
In September Prokhorov was again appointed captain of Cheboksarskyi uezd militia. This is astonishing given that he was a convicted felon, and that his unpopularity as uezd commissar had been so great that it had provoked risings and violence among the town population. The Kazan Soviet of peasants' deputies reported on 20 September that Prokhorov's appointment was again forming a heated mood among the population of both the town and the uezd. The Soviet remarked that the criminal and disruptive past of Prokhorov had not previously been clear. ${ }^{116}$ This is indicative of how little informed the Soviet was in some instances, and how information was not being shared between the Kazan committee of public safety, the Soviet of workers and soldiers' deputies and the Soviet of peasants' deputies.

Such lack of information is no explanation for the Kazan peasant Soviet's request to release Grasis and four other Cheboksary men, with an assurance that the Soviet would take full responsibility for them. ${ }^{117}$ A commission instigated by the Soviet of peasant deputies' executive committee had been formed in mid July for investigation into Grasis and the events in Cheboksary. ${ }^{118}$ Given Grasis' lack of interest in rural affairs generally, and his alleged opposition to the grain monopoly, his support by the Kazan peasant Soviet is surprising. Grasis may well have profited inadvertently from the Soviet's stated hostility to the arrests of local activists that had been perpetrated in Kazan guberniia. ${ }^{119}$ This 'tightening of the ranks' among the Soviets indicates the growing radicalism of the Kazan Soviet of peasants' deputies, and its resistance to Provisional Government bodies.

Grasis was released on 7 September, and according to his biographer, he remained in Kazan, where he agitated among the garrison, alongside Nikolai Ershov, ${ }^{120}$ 'and spoke to virtually every division individually'. ${ }^{121}$ After his release, Grasis' activities centred around Kazan town, where he was among the leaders of the Bolshevik seizure of 
power in October. Despite his new responsibilities as Bolshevik leader in Kazan, Grasis found time to return to Cheboksary:

On the 24 September Grasis returned from Kazan to Cheboksary and right away formed a meeting, at which he called the people (narod) to rout and dispersal of all public organisations ordered by the Provisional Government, and also to murder bourgeois and official individuals, by which in his speech he carried the idea of a rapid ending of the war, shouting 'Down with the war!' 122

On the basis of this fiery speech, the uezd commissar declared that Grasis was agitating the regional population, which could result in grave consequences both for him and for the uezd. Grasis was to have another place of residence named, and be banned from entering the bounds of the uezd. A soldier Smolonkov, who was a close asociate of Grasis, was also placed under court order. ${ }^{123}$ By the end of September, another command of 100 soldiers and an experienced officer from the $194^{\text {th }}$ regiment were sent to Cheboksary to be commanded by the uezd commissar, in an attempt to quell the rising disturbances. ${ }^{124}$ This resort to soldiers once again was a reflection of the rising anarchy in the town, and the inability of the Provisional Government's nominated representatives to tackle it.

Some provisional conclusions can be drawn from this assessment of events in Cheboksary, and the role of Grasis within them. Firstly, in terms of the relationship between events in the town and in the surrounding countryside, one can suggest that the division between town and countryside which was a common feature of 1917, was accentuated in Cheboksarskyi uezd by the uezd's ethnic diversity. The success of radical land policies proposed by the Kazan Soviet of peasants' deputies, and enacted by local governmental organs, forestalled the main causes for peasant disorder, and left the rural areas of the uezd relatively peaceful. Conflict over provisions was the 
defining issue in crystalising political opinion in Cheboksary. Public protest revealed what were essentially insular attitudes and refusal to embrace the broader 'national good' that the Provisional Government depended upon if it was to operate effectively. This reflects the situation seen more generally in Kazan guberniia.

Secondly, the conflicts and tendency to hysteria in sources on events in Cheboksary have been made apparent. The language of crisis was repeatedly employed, but such hyperbole was not necessarily an accurate reflection of events there. The emphasis in newspaper and Provisional Government sources on the person of Grasis as the instigator and ringleader of disorder reflects their attempts to rationalise these disorders. By naming an individual as responsible, they sought to avoid the more alarming conclusion that violent disorder and resistance to the Provisional Government's governance was a manifestation of broader popular discontent. Balance needs to be struck between the importance of Grasis as an individual and the more general conditions surrounding public unrest in Cheboksary. His importance as a local leader was evident, but many reports showed a tendency to use him as a scapegoat for a range of public disorder and protest in the uezd, some of which were only examples of traditional seasonal or food supply related disorde that was more general across the guberniia.

In contrast to many areas, where diverse administrative forms sought to work together, in Cheboksary mutually hostile power structures developed. It would be inaccurate to try to categorise this dual power as 'working people's government' (Soviet) versus 'bourgeois government' (Provisional Government). The example of Cheboksary shows that divisions in the power structures did not necessarily reflect class animosity; personal animosities were a key feature of the conflicts there. More particularly, the forceful personality of Karl Grasis himself, who established a Soviet 
that was entirely responsive to his requirements, was clearly a central feature of political life and public disorder. Grasis, despite his status as one of Kazan's foremost Bolshevik activists, was regarded and given political significance in as an individual, and not as a Bolshevik. He did not initiate any Bolshevik party work, and in fact was not widely recognised by his admirers and detractors as a Bolshevik. In Cheboksary, at least, the imprecations of political parties were less important than the individual personalities who operated in the public sphere.

The power struggle in Cheboksary highlights the inordinate power and influence wielded by soldiers within the local community. The garrison based in Cheboksary, and the soldiers moving through Cheboksary on leave were, by virtue of the arms they carried and the group mentalite and organisation implicit to military formations, a powerful and relatively cohesive group. This supports Orlando Figes' observations that soldiers were crucial leaders of revolution in rural communities during $1917,{ }^{125}$ but requires some qualification. Though the soldiers were undoubtedly influential, this did not mean that they took on roles as community leaders, but rather that they were able to operate independent of popular opinion. Ultimately, this assessment of one man's role within the socio-political context of one small town demonstrates the complexities and local specificity of political behaviour, and the ephemeral nature of popular opinion.

\footnotetext{
${ }^{1}$ By democratisation, I mean that administration was under pressure to be formed either entirely from representatives elected by the local community on the basis of four-tailed suffrage (direct, equal, secret, universal vote), or at least for existing structures to be supplemented by such popularly elected representatives. Where there was no element of 'democratisation' in an administrative body, it was unlikely to win
} 
the trust and support of the local population. A report to the Provisional Government for the period March-May nationally, commented: 'under the present system of popular elections, the idea of appointment did not fit in with the national understanding. It suspected in this practice an encroachment upon its liberties . . ' (R.P. Browder and A.F. Kerensky, [eds.] The Russian Provisional Government of 1917; Documents. [Stanford, 1961], vol. 1, p. 247, doc. 226; taken from report of the Provincial Section of the Temporary Committee of the State Duma, based on reports of its field representatives for the first three months of the revolution. The original copy of this report is held in Rossisskoi Gosudarstvennyi Istoricheskii Arkhiv [referred to throughout as RGIA] f. 1278, op. 10, d. 4)

${ }^{2}$ This dual power referred to a mirroring of the situation in Petrograd, whereby the 'bourgeois' organs of power, usually embodied in the town Duma and the 'committees of public safety' that sprang up in 1917, developed as a separate entity from Soviet power, which supposedly represented the working people. These two bodies, so the Soviet analysis goes, were essentially incompatible and destined to compete for control of the provinces. Study of the mechanism of power in the provinces has revealed that power structures involved a complex web of coalitions, partnerships and rivalries among a range of power-sharing organisations.

${ }^{3}$ There have been a number of studies of revolutionary Russia in the last fifteen years which have concentrated on a specific geographical area. Mike Hickey's collection of articles and book chapters on Smolensk are among the most significant contributions made to our understanding of the revolution in the provinces. See M.C. Hickey, 'Discourses of Public Identity and Liberalism in the February Revolution: Smolensk, Spring 1917' Russian Review 55(4) 1996, pp.615-37; M.C. Hickey, 'Local Government and State Authority in the Provinces: Smolensk, February-June 1917' 
Slavic Review 55(4) 1996, pp.863-81; M.C. Hickey, 'Urban Zemliachestva and Rural Revolution; Petrograd and the Smolensk Countryside in 1917' Soviet and Post Soviet Review 23(3) 1996, pp.142-60; M.C. Hickey, 'Big Strike in a Small City: The Smolensk Metalworkers' Strike and Dynamics of Labour Conflict in 1917'. (2000 Conference of the Study group on the Russian Revolution, Durham); M.C. Hickey, 'The Rise and Fall of Smolensk's Moderate Socialists: The Politics of Class and the Rhetoric of Crisis in 1917' in D.J. Raleigh(ed.), Provincial Landscapes: Local Dimensions of Soviet Power, 1917-1953,(Pittsburg, 2001). The two chief monographs on revolutionary Russia in the provinces are O. Figes, Peasant Russia, Civil War: The Volga Countryside in Revolution (Oxford, 1989) and D. Raleigh, Revolution on the Volga: 1917 in Saratov (New York, 1986). Other articles published more recently which reflect interest in regionally specific studies of revolutionary Russia include the work of Hugh Phillips on Tver and A. Khalid on Tashkent. (H. Phillips, '"A Bad Business"- The February Revolution in Tver' Soviet and Post Soviet Review 23(3) 1996, pp.120-41; H. Phillips, 'The Heartland Turns Red: the Bolshevik Seizure of Power in Tver'. Revolutionary Russia 14(1)2001; A. Khalid, 'Tashkent 1917: Muslim Politics in Revolutionary Turkestan' Slavic Review 55(2) 1996, pp.270-96.)

${ }^{4}$ I am currently working on a monograph which will present a comparative study of 1917 in Kazan and Nizhnii Novgorod, set in the context of popular understandings of revolution and democracy.

${ }^{5}$ For an assessment of local leadership, see S. Badcock, 'We're for the Muzhiks' Party!' Peasant Support for the Socialist Revolutionary Party during 1917' Europe Asia Studies 53(1), January 2001, pp. 133-150.

${ }^{6}$ See RGIA, f. 1278, op. 9, for list of individual files on State Duma members, for example of information available on State Duma deputies. The Gosudarstvennyi 
Arkhiv Rossisskoi Federatsii (referred to throughout as GARF) holds a huge collection of pre revolutionary political surveillance material. The enormous f. 102, with its 265 opisi, holds the former tsarist police records.

${ }^{7}$ The exception to this rule of anonymity is the memoirs of Bolsheviks produced in the Soviet period, of which there are many collections. An example of such material is Za vlast sovietov- Sbornik vospominanii uchastnikov revoliutsionnykh sobytii $v$ Tatarstane (Kazan, 1965). These memoirs, with notable exceptions, are of dubious value as a source on 1917, as their ideological dogma unfortunately overwhelms any vestige of historical accuracy.

${ }^{8}$ Generally speaking, the Soviets of workers' and soldiers' deputies met together, or had a joint Executive Committee (as in Nizhnii Novgorod), but the Soviet of peasants' deputies tended to retain independence, even if it participated in joint Soviet meetings, or publications (as in Tambov).

9 The standard reference work on the formation of Soviets is: O. Anweiler, The Soviets: the Russian Workers', Peasants' and Soldiers ' Councils 1905-1921(New York, 1974). Victor Chernov presented a very negative analysis of the Soviets' bastardised anarcho-syndicalism, as anti-democratic organisations, which offered a façade for the dictatorship of the party that controlled them. (O. Radkey, The Sickle Under the Hammer: The Russian Socialist Revolutionaries in the Early Months of Soviet Rule [New York, 1963], pp. 139-140.)

${ }^{10}$ Browder and Kerensky, The Russian Provisional Government, vol. 1, p. 247, doc. 226; taken from report of the Provincial Section of the Temporary Committee of the State Duma, based on reports of its field representatives for the first three months of the revolution. The original copy of this report is held in RGIA, f. 1278, op. 10, d. 4. ${ }^{11}$ Kazanskaia rabochaia gazeta, no. 13, $25^{\text {th }}$ April, p. 3. 
12 The 1896 census recorded a population of 4562. Taken from P.A. Chichikin, Cheboksary (Cheboksary, 1960), p. 11.

${ }^{13}$ Chichikin, Cheboksary, p. 15.

14 V.V. Tiumerov, Stranitsy iz moei zhizni. Vospominaniia. (Cheboksary, 1957), p. 13.

${ }^{15}$ Chichikin, Cheboksary, p. 16. I placed the comment on beggar peasants in inverted commas because its veracity is uncertain.

16 Tiumerov, Stranitsy iz moei zhizni, p. 12.

${ }^{17}$ Approximately $84 \%$ of inhabitants of the 12 major towns of Kazan guberniia were Russians, but only around $28 \%$ of the population outside these towns was Russian.

18 The Chuvash are thought to have been present in the mid Volga region from the middle ages, but were first mentioned in a Russian source in 1521. The Chuvash language is related to the Bulgar group of Turkic languages. In faith, some practiced Islam, while others converted to Orthodox christianity. The Marii, also an ancient Volga people, were Shamanists. Both groups retained strong national identity, and were granted autonomous oblast status in 1920.

19 Notes taken from kandidatskaia dissertation of I.M. Muliukov, 'Rukovodstvo Sovetov kul'turno-prosvetitel'nymi uchrezhdeniami v pervie godi Sovetskoi vlasti, 1917-1920gg, po materialam Kazanskoi gubernii' (Kazan, 1990, Institut iazika, literaturi I istorii imeni G. Ibragimov Kazanskago filiala ANSSSR). Miliukov's source for these figures is Tsentralnyi Gosudarstvennyi arkhiv Oktiabr'skoi revoliutsii, f. 1252, Agitatsionno-instruktorskie poezda I parakhodi VtsIK, op. 1, d. $346,1.87$.

${ }^{20}$ Only $7 \%$ of land in Cheboksarskyi uezd was held privately, in contrast to an average around the guberniia of $24.3 \%$. (Figures from E. M. Ionenko, Krestianstvo 
srednego Povol'zhia nakanune Velikogo Oktiabria [po materialam Kazanskago gubernii] [Kazan, 1957], p. 252, prilozhenie 1; Raspredelenie nadel'nikh i chastnovladel'cheskikh zemel [v desiatinakh] po uezdam Kazanskoi gubernii v 1917 godu.)

${ }^{21}$ The term 'otrubnik', loosely translated as 'seperator' generally referred to those peasants who left the village's traditional communal land holding, and instead purchased land and tried to work it as a consolidated plot.

22 The well-known Left SR Andrei Lukich Kolegaev, who was president of the Kazan Soviet of peasants' deputies, initiated this radical proposal. Such a prescient measure may well have prevented much of the more violent disorder witnessed in other guberniias. It was also a direct challenge to the authority of the Provisional Government power. Note also that otrubniki, despite their exclusion, tended to suffer; they registered a lot of complaints. (Natsionalnyi Arkhiv Respublika Tatarstana [hereafter referred to as NART], 1246, 1, 52, p. 5; published protocol of the meeting of uezd, volost commissars and secretaries of the volost committees, 15-17 June 1917.)

${ }^{23}$ Of 48 peasant seizures of land in June and the first half of July, 46 were initiated and led by volost land committees or the village skhod. (Figures V.L. Kuz'min, Krestianskoe dvizhenie $v$ Chuvashi $v$ period podgotovki Oktiabr'skoi revoliutsii, Mart- Oktiabr 1917 (Cheboksary, 1957), p. 127, p. 134.

${ }^{24}$ NART, 1246, 1, 52, p. 5; Published proclamation of the resolutions of the meeting of uezd and volost committees of Cheboksarskyi uezd, 15-17 June 1917.

${ }^{25}$ NART, f. 174, op. 1, d. 55, pp. 50-52; Journal of the general meeting of Cheboksary uezd land committee, 1 Aug. 1917.

${ }^{26}$ Kuz'min, Krestianskoe dvizhenie, pp. 75-77. 
27 Table II, showing percentage turnouts in elections of 18-28 July in volosts of

Cheboksarskyi uezd.

\begin{tabular}{|l|l|l|l|}
\hline Volost name & $\begin{array}{l}\text { \% } \\
\text { Turnout }\end{array}$ & Volost name & $\begin{array}{l}\% \\
\text { Turnout }\end{array}$ \\
\hline Cheboksar & $38 \%$ & Pokrovskii & $41 \%$ \\
\hline Togashevskii & $45 \%$ & Voskresenskoi & $43 \%$ \\
\hline $\begin{array}{l}\text { Posadko- } \\
\text { Sotnikovskii }\end{array}$ & $85 \%$ & Akulevskoi & $64 \%$ \\
\hline Pomarskoi & $53 \%$ & $\begin{array}{l}\text { Alym- } \\
\text { Kasinskii }\end{array}$ & $23 \%$ \\
\hline Nikol'skii & $24 \%$ & Pom'ialskoi & $41 \%$ \\
\hline UEZD TOTAL TURNOUT- 45\% \\
\hline
\end{tabular}

Figures taken from NART, f. 1246, op.1, d. 102, pp. 149-158; report from

Cheboksarskyi uezd commissar to the guberniia commissar, dated 9 Oct. 1917, on turn out and procedure of elections held 18-28 July 1917.

${ }^{28}$ NART, 1246, 1, 102, pp. 149-158; report from Cheboksarskyi uezd commissar to the guberniia commissar, dated 9 Oct. 1917, on turn out and procedure of elections held 18-28 July 1917.

29 E.A. Krynetskii, Kak ustanovlivalis Sovetskaia vlast v Cheboksarakh. Vospominaniia. (Cheboksary, 1957), p. 15. Note that Krynetskii's value of a source is somewhat limited by the period in which he wrote; his attempts to fit Cheboksary events within the context of orthodox Marxism-Leninism caused some grave distortions.

${ }^{30}$ Kazanskaia rabochaia gazeta, no. 10, 21 April, p. 3

${ }^{31}$ Kazanskaia rabochaia gazeta, no. 13, 25 April, p. 3, for reference to position in Cheboksary. Kazanskaia rabochaia gazeta, no. 1, 2 April, p. 2, for situation in Kazan town.

${ }^{32}$ Kazanskaia rabochaia gazeta, no. 5, 14 April 1917, pp. 2-3.

${ }^{33}$ Kazanskaia rabochaia gazeta, no. 17, 29 April 1917, p. 3. 
34 These rumours are credited to former zemstvo activists (Kazanskaia rabochaia gazeta, no. 13, 25 April 1917, p. 3)

35 These various descriptions come from a report on Grasis' activity in Cheboksary given at the guberniia provisions committee meeting on 5 July. (Kazanskaia rabochaia gazeta, no. 75, 13 July, p. 3)

${ }^{36}$ Golos Truda, no. 8, 1 June 1917, p. 4.

${ }^{37}$ NART, 1246, 1, 52, p. 414; Report from ensign Nikitin, member of the executive committee of Kazan guberniia Soviet of peasants' deputies delegates to the executive committee of the Soviet of peasants' deputies on events in Cheboksary, 24 June 1917. ${ }^{38}$ NART, f. 1246 , op. 1 , d. 52 , p. 293; report from captain of militia Svatkov in Petrograd to Kazan guberniia commissar, confirming Grasis' election as captain of the militia in Cheboksary. Undated.

${ }^{39}$ Grasis published a huge amount of material in his lifetime, much of it on literary and philosophical themes. His biographer, V. Kirillov, provides a summary of his published work. (V. Kirillov, Karl Ianovich Grasis [Cheboksary, 1969], p. 103ff.) His publications on 1917 are; Neizbezhnoe budushchee (Kazan, 1917); K natsionalnomu voprosu. Sbornik statei. (Kazan, 1918); 'Oktiabr' v Kazani' in Proletarskaia Revoliutsiia 1924, no. 10(33), pp. 120-136. He edited and write a number of articles for the Kazan newspaper Znamia Revoliutsii (Kazan, 1917-1918), Cheboksarskaia Pravda (Cheboksary, 1917-1918), and contributed to Rabochii (Kazan, 1917-1918).

${ }^{40}$ Kazanskaia rabochaia gazeta, no. 15, 27 April 1917. pp. 2-3; from the continuation of a long report on the meeting of the Kazan soviet of workers' and soldiers' deputies, 22 April 1917.

${ }^{41}$ Kirillov, Karl Ianovich Grasis, pp. 17-21. 
${ }^{42}$ Kirillov, Karl Ianovich Grasis, p. 22. Note however, that there were only around 800 workers in the town.

${ }^{43}$ NART, f. 1246 , op. 1 , d. 52 , p. 316 ; report from the Kazan military okrug staff to the guberniia commissar, 27 May 1917.

${ }^{44}$ Kirillov, Karl Ianovich Grasis, p. 33.

${ }^{45}$ Letter to the editor of Kazanskaia rabochaia gazeta from the Latt SD organisation, regarding their decision to exclude Karl Grasis, as a person moving towards a split with the principles and ideals of the revolution. His membership card was formally deactivated. (Kazanskaia rabochaia gazeta, no. 87, 27 July 1917, p. 4)

${ }^{46}$ Kirillov, Karl Ianovich Grasis, p. 31.

47 See A.V. Izorkin, entry on Grasis in Chuvashskaia Entsiklopediia (Internet Version) http://www.enc.cap.ru/open.asp?id=88\&L=5 (25 Jan 2002).

${ }^{48}$ Kirillov, Karl Ianovich Grasis, p. 32.

${ }^{49}$ Muliukov, 'Rukovodstvo Sovetov kul'turno-prosvetitel'nymi uchrezhdeniami', p. 19. Grasis worked as a Chekhist in the civil war period; he was Kazan guberniia commissar for struggle with counter revolution, and from 1919 was a political worker (politrabotnik) for the revolutionary military soviet on the eastern front. After the war he worked as a journalist. He edited and contributed to a number of newspapers and other publications in Siberia and the Povolzhe region. Grasis' published commentary on Shplenger, Zakat Evropy, is available at: http://ruthenia.ru/sovlit/j/233.html. (25 Jan 2002) His life ended in a manner common to many revolutionary activists that survived the civil war; he was arrested in 1933, and shot in 1937. His biography, written in 1969, apparently in an attempt to rehabilitate him fully, noted Grasis' direct opposition to Stalin in his time on the commission for Muslim Affairs in 1918, when Stalin was Commissar for Nationalities. (Kirillov, Karl Ianovich Grasis, p. 85) 
${ }^{50}$ Note that Krynetskii, Kak ustanovlivalis Sovietskaia vlast, pp. 13, 18, claimed that a Bolshevik cell was formed in Cheboksary during June 1917, but no mention was ever made of this cell by other Soviet sources, who generally overstated Bolshevik organisation and membership. Ia.P. Sosnin, Stranitsy proshlogo. Vospominaniia (Cheboksary, 1957) p. 11, stated that no Bolshevik organisation existed in Cheboksary by December 1917.

${ }^{51}$ Recounted in Kirillov, Karl Ianovich Grasis, p. 34.

52 This excerpt is cited by S.A. Artemev, Sovety rabochikh I krestianskikh deputatov $v$ Chuvashi v 1917-1918gg. (Cheboksary, 1965), pp. 60-61. Artemev notes the source for this article to be a file in NART. Unfortunately, when I checked this reference, the pages in question were missing from the file I believe Artemev was referring to. (NART, f. 983, op. 1, d. 1, d. 13, pp. 7-37 missing.)

${ }^{53}$ Like Grasis, Prokhorov later lost his life at the hands of the Soviet regime, though at a much earlier stage. A Soviet memoirist noted there that as a result of Prokhorov's speculation in flour he 'fell into the hands of Soviet justice' in 1921, and was shot. (Tiumerov, Stranitsy iz moei zhizni, p. 18.)

${ }^{54}$ Kazanskaia rabochaia gazeta, no. 13, 25 April, p. 3.

${ }^{55}$ Kirillov, Karl Ianovich Grasis, pp. 35-6.

${ }^{56} \mathrm{He}$ was described as 'among the most fanatic conductors of Chuvash bourgeois nationalism, who won for himself general hated from the Chuvashi people. The peasantry as well as the workers of Cheboksary abruptly condemned the counterrevolutionary activities of Prokhorov. But the bourgeois decided that they would not stop one of their ringleaders from acquitting his vile work.' (In Kuz'min, Krestianskoe dvizhenie, p. 103.) 
57 Kirillov, Karl Ianovich Grasis, pp. 35-6, on his support for the Provisional Government regime.

${ }^{58}$ Quote from Khipar cited in Kuz'min, Krestianskoe dvizhenie, p. 103.

${ }^{59}$ Rabochii, No. 25, 2 July 1917.

${ }^{60}$ NART, f. 1246 , op. 1 , d. 52 , p. 256 ; letter from guberniia commissar to Vilenskii okrug court, undated.

${ }^{61}$ NART, f. 1246 , op. 1 , d. 52, p. 259; Letter from col. Sprinnikov, military public prosecutor of Dvinskii military okrug court, to the public prosecutor of Vilenskii okrug court, 24 June 1917.

${ }^{62}$ NART, f. 1246 , op. 1, d. 52, p. 413ob; Report from ensign Nikitin, member of the Executive Committee of Kazan guberniia Soviet of peasants deputies delegates to the Executive Committee of the Soviet of peasants deputies on events in Cheboksary, 24 June 1917.

${ }^{63}$ NART, 1246, 1, 52, p. 413-413ob; Report from ensign Nikitin, member of the executive committee of Kazan guberniia Soviet of peasants' deputies delegates to the executive committee of the Soviet of peasants' deputies on events in Cheboksary, 24 June 1917.

${ }^{64}$ Kirillov, Karl Ianovich Grasis, p. 26.

${ }^{65}$ Kirillov, Karl Ianovich Grasis, pp. 32-3.

${ }^{66}$ Kirillov, Karl Ianovich Grasis, pp. 34. Penzin was also secretary of the Cheboksary Soviet. (S.A. Artemev, Sovety rabochikhi krestianskikh deputatov v Chuvashi v 19171918gg. [Cheboksary, 1965], p. 26)

${ }^{67}$ The phrase 'band of pogromists' was employed by the moderate press to describe Grasis' 'personal bodyguard'. (See Kazanskaia rabochaia gazeta, no. 76, 14 July, p. 3) 
${ }^{68}$ NART, f. 1246 , op. 1 , d. 52, p. 303; Letter from the Cheboksary committee of public safety to Cheboksary Soviet of workers and soldiers' deputies, 30 April 1917. ${ }^{69}$ NART, f. 1246 , op. 1 , d. 52 , p. 304 ; letter from the guberniia commissar to Cheboksary committee of public safety, 26 May 1917.

${ }^{70}$ This organisation at its inception was known as the Soviet of citizens' deputies, but reformed under the more usual name in mid April. (Kazanskaia rabochaia gazeta, no. 13, 25 April 1917, p. 3)

${ }^{71}$ NART, f. 1246, op. 1, d. 52, p. 414; Report from ensign Nikitin, member of the Executive Committee of Kazan guberniia Soviet of peasants deputies delegates to the Executive Committee of the Soviet of peasants deputies on events in Cheboksary, 24 June 1917. I have been unable to locate any extant copies of Cheboksarskaia Pravda; all excerpts from it are taken from secondary sources. Kuz'min notes that the records of the Cheboksary Soviet were all destroyed in June and again in December 1917. (Kuz’min, Krestianskoe dvizhenie, p. 129.)

${ }^{72}$ Kirillov, Karl Ianovich Grasis, p. 28.

${ }^{73}$ NART, f. 1246, op. 1, d. 52, p. 414ob; Report from ensign Nikitin, member of the Executive Committee of Kazan guberniia Soviet of peasants deputies delegates to the Executive Committee of the Soviet of peasants deputies on events in Cheboksary, 24 June 1917.

${ }^{74}$ NART, f. 1246, op. 1, d. 52, p. 413ob, ibid.

${ }^{75}$ Zaem Svobodi was the Provisional Government's war bonds fund set up in 1917.

${ }^{76}$ NART, f. 1246 , op. 1, d. 52, p. 414; Report from ensign Nikitin, member of the executive committee of Kazan guberniia Soviet of peasants' deputies delegates to the executive committee of the Soviet of peasants' deputies on events in Cheboksary, 24 June 1917. 
${ }^{77}$ Kirillov, Karl Ianovich Grasis, p. 31

78 NART, f. 1246 , op. 1, d. 52, p. 242ob; report from the special meeting of the revision committee, to Kazan guberniia committee of public safety, 29 April 1917.

79 The population of Kozlovko made a statement supporting the former zemstvo workers, saying that they were the first to go the people in the days of revolution. NART, f. 1246, op. 1, d. 52, p. 246; ibid.

${ }^{80}$ NART, f. 1246 , op. 1, d. 52, p. 244ob; ibid.

${ }^{81}$ The text of this whole report is NART, 1246, 1, 52, pp. 242-246; ibid.

${ }^{82}$ NART, f. 1246 , op. 1, d. 53, p. 135; letter from administration of licenced funds, to the guberniia commissar, 18 May 1917.

${ }^{83}$ Demonstrations, and attacks on provisions uprava by crowds, of very similar type to that described above, occurred in Vasil'skii, Ardatovskii and Gorbatovskii uezds in Nizhegorodskaia guberniia. (See S. Badcock, 'Support for the Socialist Revolutionary Party during 1917 , with a case study of events in Nizhegorodskaia guberniia' [PhD thesis, University of Durham, 2000], chapter 4, pp. 177-179)

84 Soldatki played a significant role in the politics of Kazan guberniia, and such demonstrations were a common method of expression for them. See S. Badcock, 'Unheralded Vanguard of Revolution? Soldiers' wives during 1917' (Unpublished paper, presented at AAASS, November 2001).

${ }^{85}$ NART, f. 1246 , op. 1, d. 52, p. 414; Report from ensign Nikitin, member of the executive committee of Kazan guberniia Soviet of peasants' deputies delegates to the executive committee of the Soviet of peasants' deputies on events in Cheboksary, 24 June 1917.

${ }^{86}$ NART, f. 1246 , op. 1, d. 52, p. 349; letter from President of Cheboksarskyi uezd provisions administration Andrei Stepanovich Kozlenkov, to the guberniia 
commissar, 6 June 1917. Note that this incident is reminiscent of many described by Barbara Engel in her article on pre-revolutionary wartime subsistence riots. (See B. Alpern Engel, 'Not by bread alone: Subsistence riots in Russia during World War 1', Journal of Modern History 69(4), Dec. 1997, pp. 696-721.)

${ }^{87}$ Kazanskaia rabochaia gazeta, no. $31,18^{\text {th }}$ May 1917, p. 3

${ }^{88}$ This comment is borne out by the frantic cries across the spectrum of Kazan newspapers regarding the shortages of sugar, white flour and tea. See also Engel, 'Not By Bread Alone', pp 718-720, on the significance of demands for non-subsistence goods like tea, sugar and white flour.

${ }^{89}$ Kuz'min, Krestianskoe dvizhenie, pp. 131-2.

${ }^{90}$ Kirillov, Karl Ianovich Grasis, p. 37.

91 This Khalapsin had reportedly been delegated from Kronstadt to Cheboksary to conduct propaganda work; at Moshtaush village, it was reported that he incited soldatki to seize wood, with the words; 'water is yours, light is yours, the land is yours, the wood is yours, you can do what you want with the wood.' (NART, f. 1246, op. 1, d. 52, p. 369: report from Cheboksarskyi uezd executive committee, 14 June 1917) Such sentiments would not have set him in good stead with the State Duma commissar, but the final indignity of being beaten up by him no doubt sealed Rossolovskii's opinion of Khalapsin.

92 NART, f. 983 , op. 1 , d. 21 , p. 31 ; Copy of telegram from Cheboksary to the guberniia commissar, undated.

${ }^{93}$ Kuz'min, Krestianskoe dvizhenie, pp. 131-2. Kuz'min adds that 'Alekseev was as counter-revolutionary as Prokhorov.'

${ }^{94}$ NART, f. 1246 , op. 1 , d. 52, p. 408; copy of telefonogram from the commissar of the State Duma, 26 June 1917. 
${ }^{95}$ NART, f. 1246 , op. 1, d. 52, p. 399; letter to captain of Kazan military okrug from the guberniia commissar, 24 June 1917.

96 NART, f. 1246 , op. 1, d. 42, p. 1; telegram from Grasis as President of the Cheboksary soviet of workers and soldiers' deputies to the guberniia commissar, 22 June 1917.

${ }^{97}$ NART, f. 1246 , op. 1, d. 42, p. 2; Telefonogram to Grasis from the guberniia commissar, 30 June 1917.

${ }^{98}$ NART, f. 1246 , op. 1, d. 52, pp. 404; telegram to Cheboksary captain of militia, 29 June 1917; 407; telegram from Kazan military okrug staff to guberniia commissar, 26 June 1917.

${ }^{99}$ Kazanskaia rabochaia gazeta, no. 75, 13 July, p. 3.

${ }^{100}$ Kirillov, Karl Ianovich Grasis, p. 39.

${ }^{101}$ Kazanskaia rabochaia gazeta, no. 84, 29 July, p. 4.

102 An extensive report from Kozmodem'ianskyi uezd, written by Kolegaev, who had been sent to investigate violence resistance to the grain monopoly there, noted that the peasants were afraid of the soldiers that had been sent to make accounts of the population and grain reserves, and whole villages had emptied, because their residents were hiding in the woods. (Izvestiia Kazanskago sovieta krestianskikh deputatov, no. 14, 18 August, pp. 2-3)

${ }^{103}$ NART, f. 1246 , op. 1, d. 52, p. 323; Telegram from guberniia commissar to Cheboksarskyi uezd commissar, 2 July 1917.

${ }^{104}$ NART, f. 1246 , op. 1 , d. 52, p. 326; Telegram from guberniia commissar to Ministry of Internal Affairs, 1 July 1917.

${ }^{105}$ NART, f. 1246, op. 1, d. 42, p. 14; Protocol of Cheboksary executive committee, 2 July 1917. 
106 NART, f. 1246, op. 1, d. 42, p. 7; Protocol of the company committee of Cheboksary garrison, 3 July 1917.

${ }^{107}$ Kazanskaia rabochaia gazeta, no. 76, 14 July, p. 3

${ }^{108}$ Recounted in Kirillov, Karl Ianovich Grasis, p. 40.

${ }^{109}$ NART, f. 1246 , op. 1 , d. 42 , p. 15; copy of declaration presented by demonstrators in Cheboksary on 3 July 1917.

${ }^{110}$ Kazanskaia rabochaia gazeta, no. 75, 13 July 1917, p. 3.

111 NART, f. 1246, op. 1, d. 42, p. 21; Protocol of general meeting of Cheboksary soviet of workers and soldiers' deputies, 7 July 1917.

${ }^{112}$ Kazanskaia rabochaia gazeta, no. 84, 29 July, p. 4

113 NART, f. 1246, op. 1, d. 42, p. 9; letter from guberniia commissar to Cheboksarskyi uezd commissar, 7 July 1917.

${ }^{114}$ From Grasis' own account, as recounted by Kirillov, Karl Ianovich Grasis, p. 41.

${ }^{115}$ Kazanskaia rabochaia gazeta, no. $84,29^{\text {th }}$ July, p. 4

${ }^{116}$ NART, f. 983 , op. 1, d. 11, p. 8; protocol of the executive committee of Kazan soviet of peasants' deputies, 20 Sept. 1917.

${ }^{117}$ NART, f. 983, op. 1, d. 21, p. 579; letter from Kazan guberniia soviet of peasants' deputies to the public prosecutor of Kazan okrug court, 16 Sept. 1917.

${ }^{118}$ NART, f. 983, op. 1, d. 13, p. 81; protocol of meeting of the executive committee of the soviet of peasants' deputies, 12 July 1917.

119 The Kazan Soviet of Peasants' deputies, led by Kolegaev, became increasingly vocal about the tactics authorised by the guberniia commissar, of arrests and military force in rural areas. See proposal made by Kolegaev opposing 'arbitrary' arrests, published in Izvestiia Kazanskago Sovieta krestianskikh deputatov, no. 8, 28 July 1917, p. 4. 
${ }^{120}$ Nikolai Evegen'evich Ershov was a prominent Bolshevik in the civil war period in Kazan, who from the end of 1917 commanded the Kazan military district. He features prominently in the street names and memorials of contemporary Kazan.

${ }^{121}$ Kirillov, Karl Ianovich Grasis, pp. 44-45.

${ }^{122}$ NART, f. 1246, op. 1, d. 42, p. 274; report about Grasis' arrest from the uezd commissar to the guberniia commissar, 29 Sept. 1917.

${ }^{123}$ NART, f. 1246 , op. 1, d. 42, p. 275; letter from Cheboksarskyi uezd commissar to the court investigator of Kazan okrug, undated but based on placement in file written just before 24 Sept. 1917.

${ }^{124}$ NART, f. 1246 , op. 1, d. 42, p. 261; military report from Kazan military okrug, 29 Sept. 1917.

${ }^{125}$ See O. Figes, 'Peasant farmers and the minority groups of rural society: Peasant egalitariansim and village social relations during the Russian revolution' in E. Kingston-Mann et al. (eds.) Peasant economy, culture and politics of European Russia, 1800-1921 (Princeton, 1991), ch. 11, pp. 393-395; O. Figes, Peasant Russia, Civil War; The Volga Countryside in Revolution (Oxford, 1989), pp. 144-147. 